Gesnerus 53 (1996) 5-14

\title{
Albrecht Haller's Patient Records (Berne 1731-1736)
}

Urs Boschung

\section{Summary}

As a young doctor Albrecht Haller (1708-1777) practised medicine in his native town, Berne, and kept a detailed case book during the years 1731 to 1736. The manuscript is preserved at the Burgerbibliothek Berne (Ms. Haller 19) and is still unpublished. It is written in Latin and documents some 2300 consultations given to 296 patients. A first attempt is made to analyse this valuable but complex source.

\section{Introduction}

Albrecht Haller ${ }^{1}$ practised medicine as a young doctor in his native town, Berne, and kept detailed patient records during the years 1731 to 1736 . Later on, as Professor of Anatomy, Botany and Surgery at the University of Göttingen (1736-1753), he was often consulted by physicians and patients, but he did not continue writing down his practical observations, nor did he hardly ever publish on medical practice.

Therefore, we deal here exclusively with Haller's early medical practice. Haller was not yet a medical authority when he wrote down his case journal.

Haller began his medical career by studying medicine in Tübingen and what is more important - in Leyden where he attended the lectures of Boerhaave and worked with Albinus for his doctoral dissertation on an ana-

1 U. Boschung, Albrecht von Haller als Arzt, Zur Geschichte des Elixir acidum Halleri, Gesnerus 24 (1977) 267-293. - For biography and bibliography see E. Hintzsche, Albrecht von Haller, C. C. Gillispie (ed.), Dictionary of Scientific Biography 6 (1972) 61-67; H. Balmer, Albrecht von Haller (Bern: Haupt, 1977); S. Lundsgaard-Hansen-von Fischer, Verzeichnis der gedruckten Schriften Albrecht von Hallers (Bern: Haupt, 1959).

Prof. Urs Boschung, M.D., Medizinhistorisches Institut der Universität, Bühlstrasse 26, CH-3000 Bern 9 
Table 1. Albrecht von Haller's curriculum vitae

\begin{tabular}{ll}
\hline 1708,16 oct. & Born in BERNE \\
$1724-1727$ & TÜBINGEN, LEYDEN: medical student \\
1727 & M.D. (Leyden) \\
$1727-1729$ & LONDON, PARIS, BASEL: academic tour, studies in anatomy and surgery \\
$1729-1736$ & BERNE: practising medicine \\
$1735-1736$ & City librarian \\
$1736-1753$ & GÖTTINGEN: professor of anatomy, botany and surgery at the University \\
1745 ff. & Member of the Council of 200 of Berne (1745-1753 in absentia) \\
1749 & Ennobled by the Emperor Franz I of Austria \\
$1753-1758$ & BERNE \\
$1753-1757$ & Head administrator of the town hall (Rathausammann) \\
$1758-1764$ & ROCHE: Director of the salt-works of the Republic of Berne \\
$1764-1777$ & BERNE \\
$1769-1777$ & Assessor perpetuus of the bord of health (Sanitätsrat) \\
1777,12 dec. & Died in BERNE \\
\hline
\end{tabular}

tomical subject. He then accomplished an academic tour to London, Paris and Basel $^{2}$. Back in Berne, he was active in the fields of botany and anatomy and had to earn his living by medical practice. In 1734 Haller was allowed by the Government to undertake anatomical studies, and a "theatrum anatomicum" was set up for $\mathrm{him}^{3}$. In the last year before he went to Göttingen, he was given the position of city librarian of Berne (1735-1736) with a salary of 30 Thalers a year. ${ }^{4}$ In 1732 his poems, soon after famous in German literature, were printed for the first time 5 .

Berne at that time was a rather small town with some 12000 inhabitants, 7 town physicians, and a dozen barber surgeons. In 1734, Haller applied in vain for one of the positions of town physician. A much elder colleague, an uncle of Haller's wife, was elected. The Hospital of Berne, the "Inselspital", founded in 1354, was attended by the town physicians; in August 1735, Haller acted as a substitute of one of the doctors who was out of town.

2 E. Hintzsche, Albrecht von Hallers Tagebuch seiner Studienreise nach London, Paris, Strassburg und Basel, 1727-1728, 2nd ed. (Bern, Stuttgart: Huber, 1968); E. Hintzsche, Albrecht von Hallers Tagebücher seiner Reisen nach Deutschland, Holland und England, 1723-1727, 2nd ed. (Bern, Stuttgart, Wien: Huber, 1971).

3 E. Hintzsche, Die geschichtliche Entwicklung anatomischer Arbeit in Bern, 1. Teil: 16.-18. Jahrhundert, Berner Zeitschrift für Geschichte und Heimatkunde (1942) 49-86.

4 H. Bloesch, Albrecht Haller als Bibliothekar. Mélanges offerts à M. Marcel Godet, Berne 1937, 165-178.

5 L. Hirzel (ed.), Albrecht von Hallers Gedichte (Frauenfeld: Huber, 1882). 
Table 2. The manuscript

\section{Burgerbibliothek Bern, Ms. Haller 19}

Paper, 197 fol., $32,5 \times 22,5 \mathrm{~cm}$, lat.

Albrecht Haller, Case Records 1731-1736 (-1738)

\begin{tabular}{llll}
\hline Period & & Registration order & fol. \\
\hline 1731 & April - Dec. & chronologically & $144 \mathrm{r}-155 \mathrm{v}$ \\
1732 & Jan. - Dec. & chronologically & $155 \mathrm{r}-164 \mathrm{v}$ \\
1733 & Jan. - Dec. & chronologically & $165 \mathrm{r}-194 \mathrm{v}$ \\
1734 & Jan. - March & chronologically & $195 \mathrm{r}-197 \mathrm{v}$ \\
& April - Dec. & chronologically & $36 \mathrm{r}-41 \mathrm{r}$ \\
1735 & Jan. & chronologically & $41 \mathrm{v}-42 \mathrm{v}$ \\
& Febr.-Dec. & by patients & $43 \mathrm{r}-138 \mathrm{r}$ \\
1736 & July-Aug. $($ hospital) & by patients & $1 \mathrm{r}-35 \mathrm{r}$ \\
1738 & Jan.-May & chronologically & $139 \mathrm{r}-143 \mathrm{r}$ \\
& & single case & $143 \mathrm{r}$
\end{tabular}

Autograph. - Bound in boards, 18th c. Manuscript lettering on the back: "Haller, Collectio Observationum Practicar(um), Mss."

Exlibris Haller with book number of Haller's library “673900”. Old signature: Milano, Bibl. Naz. Braid. AE. XIII. 6.

\section{Haller's case records}

Haller's case records are preserved at the Burgerbibliothek Bern (Ms. Haller 19$)^{6}$. The manuscript has 197 folios, is written in Latin and has remained completely unnoticed and therefore unpublished. It contains observations and prescriptions which for the most part are arranged chronologically. There are no informations whatever about financial matters. Unfortunately, the manuscript has been bound in an uncorrect order, but it seems that this mistake has been made already at Haller's time and that he had not corrected it, perhaps because he did not use this manuscript afterwards.

The manuscript has been deciphered and the text put in a new order so that the informations about single patients are compiled;family and social relations have been reconstructed where this was possible by genealogical studies and where Haller's notes were detailed. $50 \%$ of the patients are identified as

6 Haller's library as well as his manuscripts (except his collection of letters) were purchased in 1778 by the Emperor Joseph II in order to complete the Bibliotheca Braidense Brera in Milan; from there a major part of Haller's manuscripts returned to Berne in 1929 in exchange for some Italian manuscripts and as "un atto di liberalità del Governo italiano"; see L. Pecorella Vergnano, Il Fondo Halleriano della Biblioteca Nazionale Braidense di Milano (Milano: Istituto di storia della medicina, 1965); U. Boschung, Kurzinventar der Manuskripte Albrecht von Hallers (manuscript) (Bern: Burgerbibliothek, 1974). - Haller's library is still in Italy: M. T. Monti (ed.), Catalogo del Fondo Haller della Biblioteca Nazionale Braidense di Milano (Milano: Angeli, 1983-1994) (13 vols). 
Table 3. Number of patients in private practice (1731-1736) and hospital (1735)

\begin{tabular}{|c|c|c|c|c|c|c|c|c|}
\hline & \multicolumn{4}{|c|}{ Private practice (1731-1736) } & \multicolumn{4}{|c|}{ Hospital (July/August 1735) } \\
\hline & men & women & boys & girls & men & women & boys & girls \\
\hline Number & 70 & 130 & 31 & 30 & 16 & 17 & 2 & - \\
\hline$\%$ & 27 & 50 & 12 & 11 & 46 & 48 & 6 & 0 \\
\hline Total & \multicolumn{4}{|c|}{261} & \multicolumn{4}{|c|}{35} \\
\hline
\end{tabular}

e.g. father and/or mother and children, husband and wife, adult sisters, lady mistress and maid servant, etc.

Then a form for every single consultation was evaluated by computer. "Consultation" means a note which is attributed to a certain patient and in most cases is dated. The database contains 296 patient records and some 2300 consultation records.

\section{Patients and consultations}

A first analysis reveals that Haller was consulted by 296 patients; $12 \%$ are patients attended by him in the hospital in summer $1735.50 \%$ of the private patients are women, $22 \%$ children and adolescents (17 years or less old), and only $27 \%$ are adult men. This confirms the thesis that the medical beginner had mainly women and children.

A part of these patients belong to the prominent, even to the leading families of Berne. Others are craftsmen, traders, employees or servants. For others as for instance the hospital patients, the social position is not mentioned but can be supposed to be low. Only few country people consulted Haller; typically their family name is not mentioned. The final analysis of the details concerning patients is not yet made. It will also be important to see which families did not appeal to Haller; it seems that he was friendly with the antiFrench party and was avoided by the pro-French one.

67 patients had only 1 consultation, 117 are seen by their physican 2 to 5 times, 13 patients 31 ore more times. On top of the list is a lady who has 119 consultations; she is the wife of the "Schultheiss", the head of the government of Berne and the great-aunt of Haller's wife.

It is interesting to see how the consultations are distributed over the time. There are two main peaks due (1) to the $1732-1733$ influenza pandemic ${ }^{7}$ and

7 K. D. Patterson, Pandemic Influenza 1700-1900, A Study in Historical Epidemiology (Totowa: Rowman \& Littlefield, 1986) 16. 
Table 4. Number and average numbers of consultations per patient in private practice (1731-1736) and hospital (1735)

\begin{tabular}{|c|c|c|c|c|c|c|c|c|}
\hline \multirow{2}{*}{$\begin{array}{l}\text { Consultations } \\
\text { per patient }\end{array}$} & \multicolumn{4}{|c|}{ Private practice (1731-1736) } & \multicolumn{4}{|c|}{ Hospital (July/August 1735) } \\
\hline & men & women & boys & girls & men & women & boys & girls \\
\hline 1 & 22 & 29 & 2 & 6 & 5 & 3 & - & - \\
\hline $2-5$ & 26 & 52 & 13 & 10 & 8 & 8 & - & - \\
\hline $6-10$ & 8 & 17 & 7 & 6 & 2 & 5 & 1 & - \\
\hline $11-20$ & 10 & 19 & 5 & 4 & 1 & 1 & 1 & - \\
\hline $21-30$ & 2 & 3 & 2 & 2 & - & - & - & - \\
\hline $31-50$ & 2 & 7 & 2 & 2 & - & - & - & - \\
\hline$>50$ & - & 3 & - & - & - & - & - & - \\
\hline $\begin{array}{l}\text { Average number } \\
\text { of consultations }\end{array}$ & 6.1 & 8.7 & 9.8 & 9.7 & 3.9 & 5.2 & 9.5 & 0 \\
\hline
\end{tabular}

Table 5. Distribution of consultations (1731-1736)

consultations / month (Private Practice, Hospital)

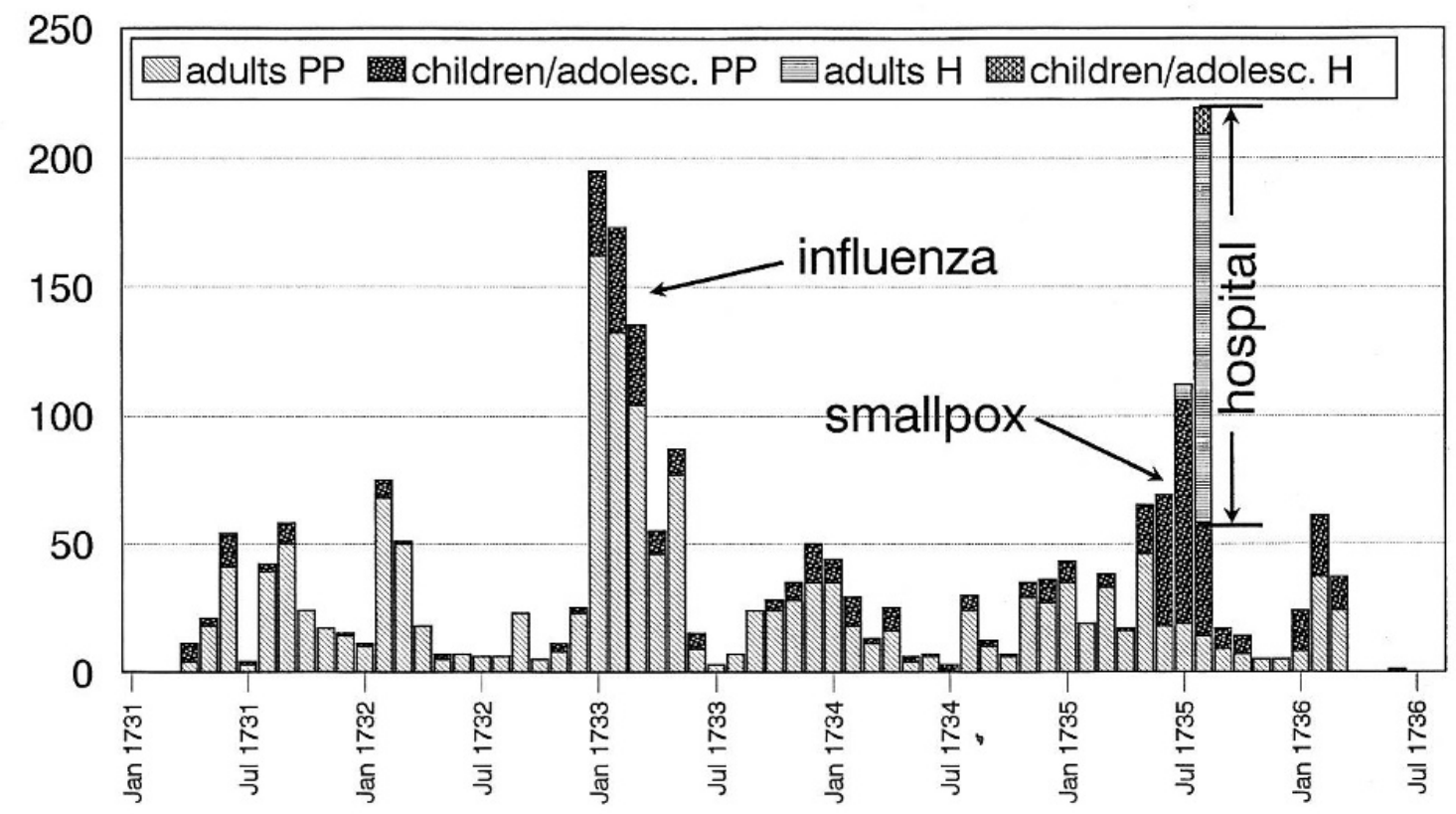

(2) in summer 1735 to a couple of smallpox cases and to hospital service. In other summers, Haller was out of town on botanical excursions in the alps; therefore his medical practice was rather reduced.

Whereas the records begin in April 1731 Haller's correspondence proves that he started practice as soon as he was back in Bern in 1729 when his friend Giller teases him as "médecin des demoiselles"8. Did he start writing down his observations only in April 1731, and if so, why? We have not yet found the

8 C. Wegelin, Briefe des St. Galler Stadtarztes Peter Giller an Albrecht von Haller, Gesnerus 7 (1950) 5; Burgerbibliothek Bern, N Albrecht von Haller, Korrespondenz Giller, 17 may 1729. 
reason. First we thought that he might have destroyed the earlier notes. On the other hand, there are clear differences between the first records of the journal and the later ones, because in the beginning, in April and May 1731, Haller did not give proper names to his patients; he speaks of a "puer trium annorum" or a "vir obesus". In June then, as it apparently became difficult to dinstinguish a dozen or more persons, he changed his method and noted his patients by their names, e.g. "Virgo Apollonia Fischer", "Domina Maria Steiger", "Puella Altmann".

There are many indications that the case book was written day by day or at least at very short time intervals. It remains undecided whether all consultations were recorded. A lot of very trivial and simple health troubles are mentioned so that it seems very unlikely that only the interesting cases were noted down.

\section{Diagnoses}

Haller did not systematise his notes and observations, neither in regard to the single patient's case nor to symptoms or diagnoses. So it is difficult to characterize his medical practice and its theoretical basis. In most cases he simply described the symptoms and avoided to give them the more general name of some disease. The symptomatology is based on the complaints of the sick and on observations of his strength and appetite, on pulse, urine and other excreta, local signs, etc. We can not confirm the statement of Haller's biographer Zimmermann, that he used a watch with a second-hand for counting the pulse $^{9}$. On the contrary, pulse frequency is always noted in words (for instance "celer", "citus", "citissimus", "moderatus", "naturalis", "lentus").

In order to systematise the consultation records we are trying to create a systematic list of diagnoses and symptoms which is based on Haller's own terms. We further try to single out the individual cases and to give them what is the most difficult - a final diagnosis. For their evaluation we plan to follow the system adopted by Risse in his book on the Royal Infirmary of Edinburgh (1986) ${ }^{10}$.

As a trial we picked out the 480 consultations concerning adult men, that is 86 patients or 124 cases (several men have been treated for more than one disease).

Table 6. Haller's cases of adult men (86 patients, 124 cases, 480 consultations, Berne, 1731-1736) compared to 3047 cases (all patients) of The Royal Infirmary of Edinburgh (1770-1800)

9 J. G. Zimmermann, Das Leben des Herrn von Haller (Zürich: Heidegger, 1755) 96-97.

10 G. B. Risse, Hospital Life in Enlightened Scotland (Cambridge: Cambridge University Press, 1986). 


\begin{tabular}{lcl}
\hline & Berne & Edinburgh \\
\hline Genitourinary diseases & $11.2 \%$ & $\mathbf{2 0 . 6} \%$ \\
Infectious diseases (med.) & 12 & 15.6 \\
Respiratory diseases & $\mathbf{2 3 . 3}$ & 11.1 \\
Musculoskeletal disorders & 6.4 & 5.9 \\
Diseases of the digestive system & 10.4 & 6.5 \\
Neurological/mental diseases & $\mathbf{1 5 . 2}$ & 5.3 \\
Diseases of the skin & 4 & 4.1 \\
Circulatory disorders & 1.6 & 2.6 \\
Eye problems & 2.4 & 2 \\
Miscellaneous med. conditions & 2.4 & 2 \\
Surgical infections & 0.8 & $\mathbf{1 1 . 4}$ \\
Traumatic conditions & 3.2 & 4.9 \\
Tumors, cancers & 3.2 & 2.5 \\
Surgical procedures & 1.6 & 0.6 \\
Miscellaneous surgical conditions & 1.6 & 1.2 \\
Unknown & 0 & 3.6 \\
\hline
\end{tabular}

Our results are not final at all. The so-called "final diagnosis" which decides where the case has to be classified, is to be checked again and again, and rules are to be established how the diagnosis should be attributed in complex cases. The results will further differ when children and women enter into the statistics. Among them, diseases of the digestive system as well as menstrual disorders and hysterical symptoms will be most frequent.

It is clear that Haller's thinking was strongly influenced by humoralism, but there is also localism and a pathology of forces and of nerves. From April 1731 until September 1733 Haller took notes on weather, barometer and thermometer. So it is probable that he thought of "epidemic constitution", a term used by him in the context of the smallpox epidemic of $1735^{11}$.

It is obvious to ask for the works of medical authors Haller was reading in these years. We have several hundred summaries (Judicia librorum) he made in this period and which are still existing in the Burgerbibliothek Bern ${ }^{12}$. Among them we find notes on Hippocrates, Sydenham, Boyle, Boerhaave, Friedrich Hoffmann and many others. However, these summaries are not yet analysed.

11 A. Haller, Historia constitutionis variolosae, Commercium litterarium ad rei medicae et scientiae naturalis incrementum institutum, hebd. decima, Norimbergae, 7 march 1736, 73-78.

12 Burgerbibliothek Bern, Ms. Haller 32-34. 


\begin{tabular}{lrr}
\hline & $\mathrm{n}$ & $\%$ \\
\hline bene & 111 & 9.4 \\
melius & 172 & 14.6 \\
convaluit & 78 & 6.6 \\
sanatus & 16 & 1.4 \\
feliciter & 427 & 36.3 \\
dubius & 140 & 11.9 \\
male & 14 & 1.2 \\
pejus & 21 & 1.8 \\
infeliciter & 198 & 16.8 \\
\hline
\end{tabular}

\section{Therapy}

To evaluate Haller's therapy is the next problem. As a preliminary study a catalogue of drugs and therapeutic measures is being made which shows their occurrence and the composition of the single drugs in Haller's presciptions. Our database contains a field "Therapy" which permits to retrieve every single term. The search for "venaesectio", for instance, yields 103 entries, which in combination with the fields "diagnosis" and "success" will enable us to make a statement about indications, importance, and supposed effect of bloodletting as well as other different therapeutic measures. Much work remains to be done on this aspect.

In the database field "success" we registered Haller's notes concerning the effect of his prescriptions. $50 \%$ of consultations contain such remarks. A rough evaluation shows that the doctor could feel (or felt) rather satisfied with his success. The effect of therapy was judged by him positive in $68 \%$ of cases, dubious in $10 \%$, and negative in $20 \%$.

In the course of the years 1731-1736 Haller noted the death of 28 persons (19 adults, 9 children and adolescents); 5 of them were not his patients; in 5 cases a post mortem examination was performed by him or in his presence.

\section{Haller's publications}

As said in the beginning, Haller did not evaluate and publish his practical experiences. But there are some exceptions. The "Commercium litterarium ad rei medicae et scientiae naturalis incrementum institutum", which was edited in Nuremberg by Christoph Jacob Trew (1695-1769), contains short reports about the post-mortem examination of two of Haller's patients of 1732 
Table 8. Cases of death

\begin{tabular}{|c|c|c|c|c|}
\hline 1732 & 1733 & 1734 & 1735 & 1736 \\
\hline $\begin{array}{l}30 \mathrm{~m} \\
\frac{18 \mathrm{~m}}{(\mathrm{~A} \mathrm{~m})} \\
68 \mathrm{f} \\
(\mathrm{A} \mathrm{f})\end{array}$ & $\begin{array}{l}\left(\frac{31 \mathrm{~m}}{\mathrm{Am}}\right) \\
\mathrm{Am} \\
\mathrm{Am} \\
(55 \mathrm{f}) \\
\frac{49 \mathrm{f}}{\mathrm{Af}}\end{array}$ & $\begin{array}{c}74 \mathrm{~m} \\
1 \mathrm{~m} \\
8 \mathrm{f} \\
3 \mathrm{f} \\
\mathrm{Aff}\end{array}$ & $\begin{array}{c}30 \mathrm{~m} \\
11 \mathrm{~m} \\
1 \mathrm{~m} \\
(\underline{\mathrm{A} \mathrm{m}}) \\
74 \mathrm{f} \\
50 \mathrm{f} \\
17 \mathrm{f} \\
8 \mathrm{f}\end{array}$ & $\begin{array}{r}29 \mathrm{~m} \\
29 \mathrm{f}\end{array}$ \\
\hline 5 adults & 7 adults & $\begin{array}{l}2 \text { adults } \\
3 \text { children }\end{array}$ & $\begin{array}{l}4 \text { adults } \\
4 \text { children }\end{array}$ & $\begin{array}{l}1 \text { adult } \\
2 \text { children }\end{array}$ \\
\hline $\begin{array}{l}\text { number } \\
\text { A } \\
\mathrm{m} \\
\mathrm{f} \\
(\text { ) } \\
\text { underlining }\end{array}$ & \multicolumn{4}{|c|}{$\begin{array}{l}=\text { age in years } \\
=\text { adult } \\
=\text { male } \\
=\text { female } \\
=\text { death noted by Haller. Not his patient } \\
=\text { Post mortem done by Haller / in presence of Haller }\end{array}$} \\
\hline
\end{tabular}

and $1735^{13}$. In March 1736 the "Historia constitutionis variolosae anni 1735" appeared in the same journal ${ }^{14}$. These texts were later reprinted in Haller's "Opuscula pathologica" and "Opera minora anatomica" and supplemented by several other case reports ${ }^{15}$.

In his article on the smallpox epidemic of Berne Haller cites Sydenham's merits in this field but deplores that he declared the "maculae nigrae" as a lethal symptom ${ }^{16}$. Haller says that he looked for a remedy to treat these "maculae nigrae" and that he found it in the internal use of camphor. Camphor had been praised for its "virtus refrigerans" by Tralles, but only in theory and not by experience ${ }^{17}$.

13 A. Haller, Ea quae in sectione phthisici observavit, Commercium litterarium ad rei medicae et scientiae naturalis incrementum institutum, hebd. 24, Norimbergae, 16 June 1734; Observatio de peripneumonia contagiosa et perniciali, ibid., hebd. II., 12 Jan. 1735.

14 See note 11 .

15 A. von Haller, Opuscula pathologica (Lausanne: Bousquet, 1755) (various editions); A. von Haller, Operum anatomici argumenti minorum tomus tertius, accedunt Opuscula pathologica (Lausanne: Grasset, 1768) 277-388.

16 See note 11.

17 B. L. Tralles, Exercitatione physico-medica virtutem camphorae refrigerantem ac internis corporis humani incendiis restinguendis aptissimam edisserit, atque ex genuinis artis principiis adstruit ... (Vratislaviae et Lipsiae: Hubertus, 1734). - Haller claims that at the time of the epidemic he had not yet seen Tralles' book: «Quam quidem vim [camphorae] neque tunc didici ex scripto nondum ad nos delato, neque nunc in eodem reperio, sed ex ipsa natura expiscatus, in praxin deduci.» (Comm. litt. [cited in note 11] 1736, 74). Neither does he cite F. Hoffmann, C. H. Keil, Dissertatio medica De usu interno camphorae securissimo et praestantissmo (Halae: Zeitler, 1714). 
Two other cases concerning the years 1731-1736 were published by Haller in his edition of Boerhaave's "Consultationes medicae", Göttingen $1752^{18}$. $\mathrm{He}$ had consulted his teacher Boerhaave because both patients were prominent persons of Berne, and Haller and his colleagues disagreed in their opinion what should be done. In one of these cases the patient was advised by Haller to travel to Leyden; he did so and died in Leyden in the same year (1737).

\section{Some final remarks}

Haller as a physiologist is usually supposed to be a theorist and an experimental scientist. This paper shows that he had also practical experience in medicine. Whether his way of thinking is based on this practical experience remains to be investigated in detail. Anyway, we should not project our conception of specialised science which is separated from medical practice into the 18 th century.

In this study nothing is said about Haller's relationship with his patients. In the case records numerous notes exist on opinions and behaviour of patients and on other doctors and healers. These aspects are to be analysed in the context of the historical and social situation of the Bernese society. The results will elucidate both what Risse calls the "social ritual very much shaped by the prevailing cultural milieu" 19 and the situation in which Haller wrote his socio-critical and satirical poems "Die verdorbenen Sitten" (Corrupted morals, 1731) and "Der Mann nach der Welt" (The man in fashion, 1733) ${ }^{20}$. Contrary to others, Haller chose the inductive method to codify his experience in medical practice. However, he did not systematize it nor did he evaluate it. That is what makes it difficult to the historian to analyse his case records, but also what makes it so exciting to see "what a physician really did" $(\text { Risse })^{21}$.

Paper read at the International Conference "The History of Case Histories" in Stuttgart, 25 September 1991.

18 [A. Haller, ed.,] Consultationes medicae sive syllogae epistolarum cum responsis Hermanni Boerhaave, in Britannia primum editae, nunc aliquot exemplis auctiores, adcesserunt eiusdem Introductio ad Praxin Clinicam \& Praelectiones de Calculo. Editio Gottingensis altera emendata (Gottingae: Vandenhoeck, 1752) 18-22 (Gottlieb von Diesbach, 1671-1735; Emanuel von Graffenried von Gerzensee, born 1692 in Berne, died in Leyden in 1737).

19 G. B. Risse, The History of Therapeutics, Clio medica 22 (1991) 3-11, p. 6.

20 L. Hirzel (cited in note 5), p. 86-98, 102-108.

21 G. B. Risse (cited in note 19), p. 7. 